\title{
Amending Subsoil with Composted Poultry Litter-I: Effects on Soil Physical and Chemical Properties
}

\author{
Mili Mandal ${ }^{1,2}$, Rakesh S. Chandran ${ }^{1, *}$ and John C. Sencindiver ${ }^{1}$
}

1 Division of Plant \& Soil Sciences, West Virginia University, Morgantown, WV 26506-6108, USA; E-Mail: jsencind@wvu.edu

2 Department of Pharmacology and Toxicology, Ernest Mario School of Pharmacy, Rutgers University, Piscataway, NJ 08854, USA; E-Mail: mandal@rci.rutgers.edu

* Author to whom correspondence should be addressed; E-Mail: rschandran@mail.wvu.edu; Tel.: +1-304-293-2603; Fax: +1-304-293-6954.

Received: 14 August 2013; in revised form: 14 September 2013 / Accepted: 29 September 2013 / Published: 21 October 2013

\begin{abstract}
During construction disturbance, topsoil is often removed and turfgrasses are established in poor soils. Our study determined the effects of amending subsoil with composted poultry litter on physical and chemical properties that affect turfgrass growth attributes. To simulate typical disturbance conditions, $20 \mathrm{~cm}$ of topsoil was removed from a Dormont silt loam (fine-loamy, mixed, superactive, mesic Oxyaquic Hapludalfs) and composted poultry litter was incorporated at 0.1 , or 0.2 , or $0.4 \mathrm{~cm} / \mathrm{cm}$-soil into the exposed subsoil to a depth of $12.7 \mathrm{~cm}$ before growing turf. Composted plots were compared to $\mathrm{N}$-fertilized $\left(50 \times 10^{-4} \mathrm{~kg} \mathrm{~m}^{-2}\right)$ and control plots. Linear increases in total water content, organic matter, $\mathrm{pH}$, and basic cations were observed following compost incorporation. Composted poultry litter increased total water content by $38 \%$ and decreased soil bulk density by $42 \%$. Compost applications increased organic matter by $5.8 \%-6.4 \%$, along with an increase in $\mathrm{pH}$ from 6.0-7.4. The cation exchange capacity increased up to $186 \%$ in compost-incorporated plots. No differences were observed between fertilized and control plots for all soil properties except for P levels, which increased in fertilized plots. Overall, compost treatments improved soil physical and chemical properties compared to conventionally fertilized and control plots.
\end{abstract}

Keywords: amendment; improving turf medium; turfgrass; urban lawn establishment 


\section{Introduction}

Topsoil on sloping landscapes in the Appalachian region is often thin, rocky and infertile [1]. The topsoil is usually lost or is mixed with subsoil during the construction process. Lawns established under such conditions are not healthy and may be vulnerable to pest problems. Amending such soils with suitable composts may improve the medium for turfgrass growth. Composted poultry litter (CPL) contains several plant macronutrients and micronutrients and has been considered as a valuable soil amendment to enhance soil fertility, organic matter, and tilth [2-6]. Improper use and disposal of poultry litter may have detrimental effects on environment and human health. Instances of diseases such as methemoglobinemia, cancer, and respiratory illness have occasionally been attributed to $\mathrm{NO}_{3}{ }^{-}$leaching from poultry litter [5,7-8]. Other undesirable attributes such as eutrophication, production of phytotoxic substances, air pollution, and emission of ozone depleting gases have also been associated with improper disposal of this waste product [7].

Composting may mitigate the environmental problems associated with the application of raw poultry litter and may provide a beneficial method for handling this waste product of the poultry industry. Along with the reduction in odor, pathogens, and weeds, composting also immobilizes highly mobile $\mathrm{NO}_{3}{ }^{-}$in the litter to its slow-release form [9-11]. It is also easier to handle, store, transport, and apply litter that has been composted [12]. Composting also reduces total phosphorus $(\mathrm{P})$, due to dilution of manure with woodchips and straw [13].

Considerable data on the effect of various organic materials on soil physical and chemical properties are available. Sewage sludge reduced bulk density and increased soil water content, available water, $\mathrm{CEC}$, and soil $\mathrm{pH}[14,15]$. Municipal solid waste increased nutrient and water retention capacity, total pore space, and aggregate stability, and decreased cone penetration resistance and bulk density [16,17]. Cattle feedlot litter increased soil organic carbon and water stable aggregates, and decreased bulk density and hydraulic conductivity of disturbed soils [18]. Application of poultry litter on pasture soils over a 20 -yr period altered soil properties $(\mathrm{pH}$, electric conductivity, and bulk density) macrocation levels (Ca, K, Mg and Na levels), and increased hay yields [19]. In this study, the authors also noted that the labile form of phosphorus increased following long-term sequential application of poultry litter. Similar conclusions were drawn by Gascho and Hubbard [20] when broiler litter was used to amend soils over a 5 -yr period.

The effects of different types of compost materials as an amendment for lawns and other types of turf have been well documented [21-25]. While sequential applications of poultry litter over multiple years may result in undesirable effects to the environment, single incorporation of the same as compost to the subsoil may be beneficial. Limited information is available on the effect of composted poultry litter (CPL) on infertile subsoil as it relates to turf production. The objective of this experiment was to evaluate the changes in physical and chemical properties of subsoil as a result of using CPL as a soil amendment. In a related field experiment, the effects of amending a subsoil using CPL on the growth attributes of Kentucky bluegrasss (Poa pratensis L.) and weed populations were investigated [26]. Turfgrass was chosen as the plant material due to its ubiquitous nature in the landscape typically established in housing and other developments with poor soil quality and a minimal A-horizon. 


\section{Results and Discussion}

\subsection{Soil Physical Properties}

\subsubsection{Total Water Content and Soil Organic Matter}

The subsoil was determined to be a silt loam. The effects of compost rates on total water content, $\theta_{T}$, are presented in Figure 1. For both seeded and sodded treatments, percent soil water content was higher in compost-treated plots than in fertilized and control plots and increased linearly with percent compost (sodded, $R^{2}=0.95$; seeded, $R^{2}=0.73$ ). There was an increase in organic matter content due to initial addition of CPL into the subsoil (sodded $R^{2}=0.94$; seeded $R^{2}=0.98$ ) but differences in the same could not be determined with subsequent incorporation rates of CPL (Figure 2).

The increases in $\theta_{T}$ may be associated with the increase in organic matter and its effect on soil physical properties. Organic matter is capable of absorbing up to 20 times its weight of water [27]. This ability is related to the large number of hydrophilic aromatic and aliphatic compounds in the organic matter structure [28]. Organic matter also acts as a cementing agent between soil particles, thereby improving aggregation and increasing porosity [27]. This process of aggregation improves water infiltration, soil tilth, and subsequently plant growth especially in loamy soils.

Figure 1. Effect of incorporating composted poultry litter into top $12.7 \mathrm{~cm}$ of subsoil on percent total water content $\left(\theta_{T}\right)$ by volume for $\bullet$ sodded compost; $\circ$ sodded fertilizer; seeded compost; and $\nabla$ seeded fertilizer plots; * Means with same letters are statistically insignificant based on Fisher's Protected LSD test $(P \leq 0.05)$ (italicized statistics correspond to sodded treatments); ${ }^{\dagger}$ values for standard error were small ranging between 0.085 ( $\mathrm{min}$.) to 0.553 (max.) and hence are not shown in figure.

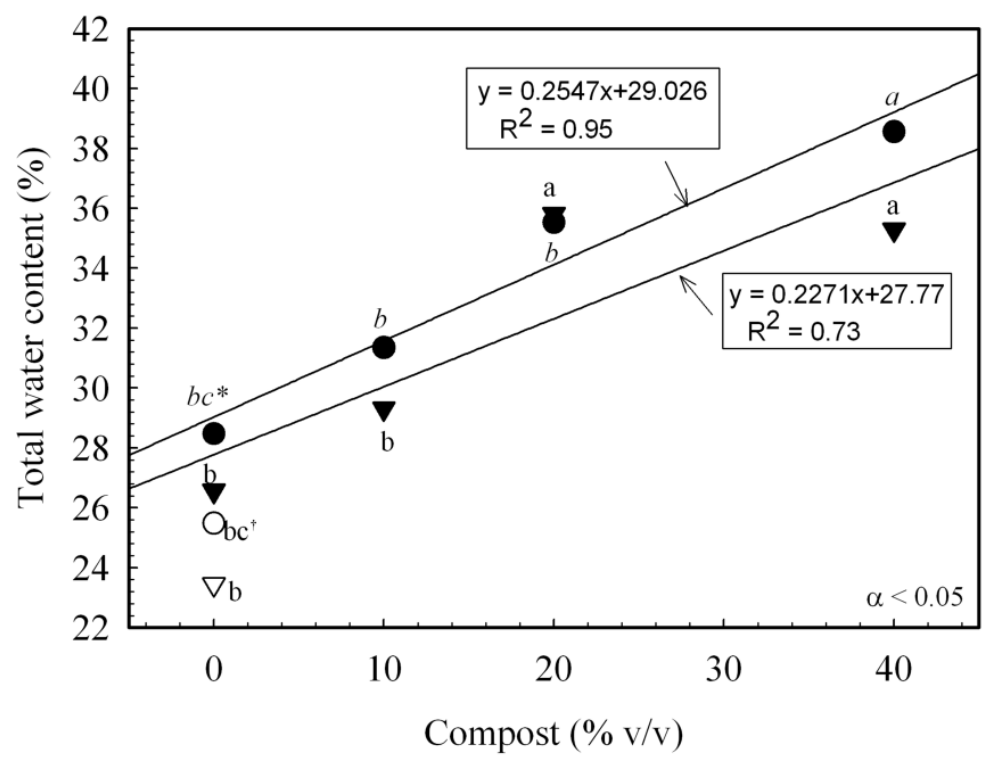


Figure 2. Effect of incorporating composted poultry litter into top $12.7 \mathrm{~cm}$ of subsoil on organic matter for $\bullet$ sodded compost; $\circ$ sodded fertilizer; $\boldsymbol{\nabla}$ seeded compost; and $\nabla$ seeded fertilizer plots; * Means with same letters are statistically insignificant based on Fisher's Protected LSD test $(P \leq 0.05)$ (italicized statistics correspond to sodded treatments).

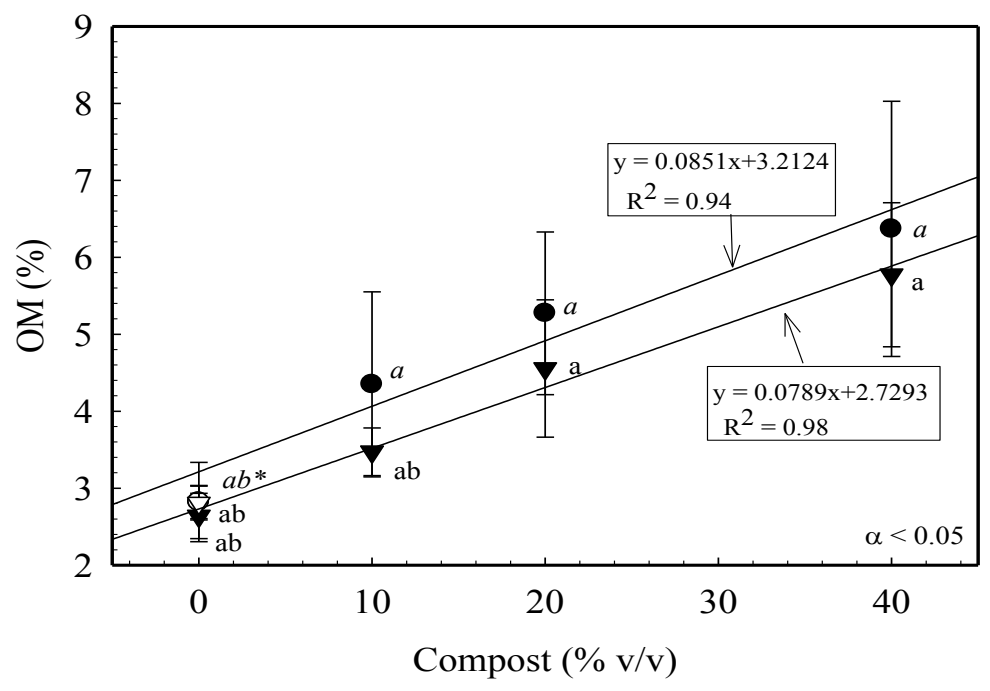

\subsubsection{Available Water Capacity and Soil Bulk Density}

A linear negative relationship (sodded, $R^{2}=0.89$; seeded, $R^{2}=0.97$ ) was observed between percent compost and available water, $A_{v}$ (Figure 3). As percent compost increased, $A_{v}$ decreased (Figure 3 ) whereas the total amount of water in soil increased (Figure 1). This suggests that the higher the compost rate, the larger is the total volume of water held by soils and lower is the volume available for plant uptake which indicates that more water is retained by soil particles.

Figure 3. Effect of incorporating composted poultry litter into top $12.7 \mathrm{~cm}$ of subsoil on available water, $A_{v}$ for $\bullet$ sodded compost; $\circ$ sodded fertilizer; $\nabla$ seeded compost; and $\nabla$ seeded fertilizer plots; * Means with same letters are statistically insignificant based on Fisher's Protected LSD test $(P \leq 0.05)$ (italicized statistics correspond to sodded treatments).

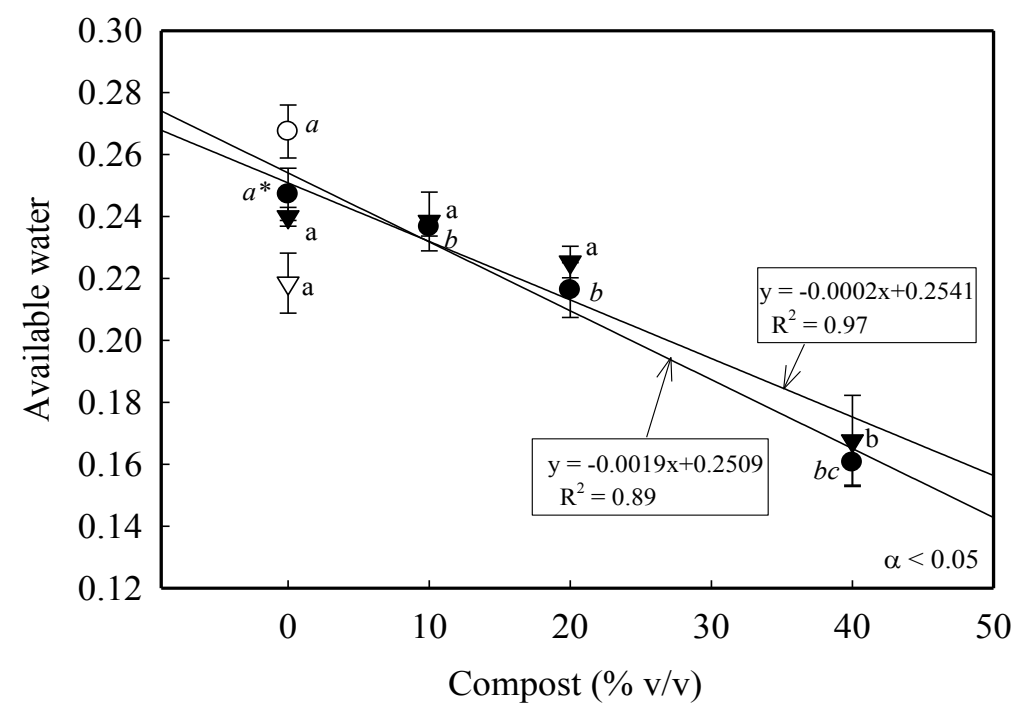


In this study, we determined both $\theta_{T}$, and $A_{v}$, since each measured a different pool of water. Soil water content measures the total amount of water held by soil $\left(\theta_{T}=A_{v}+\right.$ Unvailable $)$ whereas $A_{v}$ determines the amount of water that can be extracted by plants. This water is held between field capacity and wilting point by capillary forces [29].

Organic matter addition has been reported to increase $A_{v}$ only in coarse textured soils with $<15 \%$ clay. With soils having $>15 \%$ clay such as the soil used in this study (24\% clay), factors other than organic matter determine $A_{v}$ [30]. Reports on the effects of compost on $A_{v}$ ranged from increase, decrease, and no change of $A_{v}$ with compost additions, and, were related to variation in the soil physical properties such as texture, pore size distribution [5], percent clay and structure [30], and bulk density [31,32].

Angle et al., [33] reported an increase in $\theta_{T}$ of soil with increased rate of sludge compost but observed no effect on $A_{v}$. Jamison and Kroth [34] attributed the changes in $A_{v}$ to the increase in either percent silt or clay and their effect on pore size distribution. They concluded that the clay particles in silt loam soils with more than $20 \%$ clay reduced the water storage by diluting the soil mass and shifting the pore size distribution towards smaller pores, where more water is held in the unavailable range. Metzger and Yaron [35] observed an increase in $A_{v}$ of sandy soils, whereas that of a loamy soil remained unchanged upon addition of sludge. MacRae and Mehuys [36] reported a decrease in $A_{v}$ in silt loam following the addition of peat at different rates.

Stevenson [37] explained that the net result of addition of organic material on $A_{v}$ depends on the relative changes in percent water by weight of soil $\left(W_{15}-W_{1 / 3}\right)$ and decreases of bulk densities dictated by soil type. For silt loam, he associated the decrease in $A_{v}\left(\right.$ at $\left.0.3 \times 10^{5} \mathrm{~Pa}\right)$ to a consistent decrease in soil bulk density with peat moss addition. These observations agree with our results (Figure 4). We recorded a decrease in $A_{v}$ of a silt loam from addition of CPL along with a decrease in bulk density (Figures 3 and 4).

Soil bulk density decreased linearly, up to $42 \%$ with $40 \%$ compost, with increasing rates of compost (sodded, $R^{2}=0.98$; seeded, $R^{2}=0.97$ ) (Figure 4). Decrease in bulk density is generally associated with the low particle density of organic matter, which when mixed with the mineral fractions of soils greatly improves aggregation and porosity [36]. The reduction in the soil bulk density with organic material addition is also related to factors such as compost application rate, soil type, and extent of soil compaction [37]. Wei et al. [38] also observed a $6.3 \%$ decrease in bulk density of silty clay loam by the application of sludge compost at $1.34 \times 10^{-8} \mathrm{~kg} \mathrm{~m}^{-2}$.

\subsection{Soil Chemical Properties}

The subsoil was determined to have a pH of 6.0 and CEC of $11 \mathrm{cmol}_{\mathrm{c}} \mathrm{kg}^{-1}$. The addition of CPL to subsoil increased its $\mathrm{pH}$ linearly (sodded, $R^{2}=0.97$, seeded, $R^{2}=0.84$ ) from 6.0 (control) to 7.4 (0.4 cm-compost/cm-soil) (Figure 5). An increase in the availability of soil basic cations also was observed as a result of compost addition (Table 1). These effects may be explained by the initial high $\mathrm{pH}$ of 8.3 of CPL and its high basic cation content (Table 1) and a possible increase in availability of inherent cations associated with the $\mathrm{pH}$ change. Increases in soil $\mathrm{pH}$ through compost application (poultry litter) were also reported by Rasnake and Murdock [39]. They attributed this increase to the high $\mathrm{Ca}$ content of poultry litter and its effect on exchangeable soil $\mathrm{Ca}$. However, in a more recent study, 
application of broiler litter had no effect on total soil $\mathrm{pH}$ nor was there any interaction between broiler litter rate and depth [20].

Figure 4. Effect of incorporating composted poultry litter into top $12.7 \mathrm{~cm}$ of subsoil on soil bulk density for $\bullet$ sodded compost; $\circ$ sodded fertilizer; $\boldsymbol{\nabla}$ seeded compost; and $\nabla$ seeded fertilizer plots; * Means with same letters are statistically insignificant based on Fisher's Protected LSD test $(P \leq 0.05)$ (italicized statistics correspond to sodded treatments).

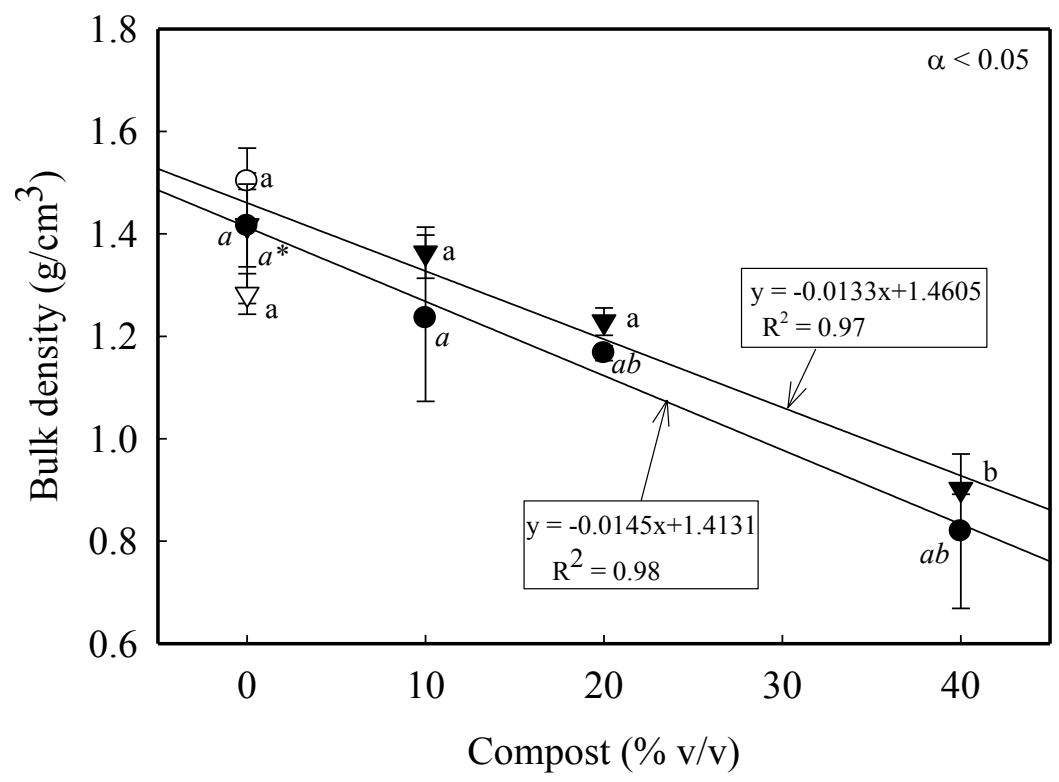

Figure 5. Effect of incorporating composted poultry litter into top $12.7 \mathrm{~cm}$ of subsoil on soil $\mathrm{pH}$ for $\bullet$ sodded compost; $\circ$ sodded fertilizer; $\nabla$ seeded compost; and $\nabla$ seeded fertilizer plots; * Means with same letters are statistically insignificant based on Fisher's Protected LSD test $(P \leq 0.05)$ (italicized statistics correspond to sodded treatments).

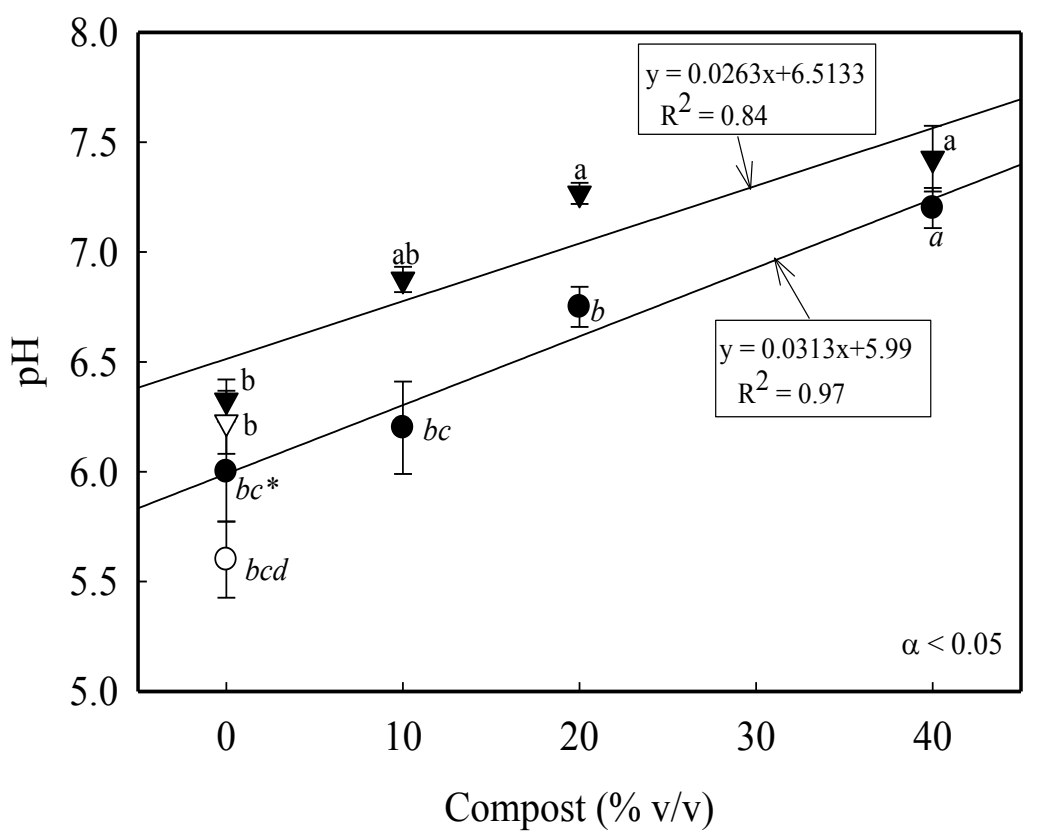


Table 1. Effect of incorporating composted poultry litter into top $12.7 \mathrm{~cm}$ of subsoil on its mineral nutrient content; * Means with same letters are statistically insignificant based on Fisher's Protected LSD test $(P \leq 0.05)$.

\begin{tabular}{ccccc}
\hline Treatment (cm-compost/cm-soil) & P & K & Ca & Mg \\
\hline & \multicolumn{5}{c}{ Seeded } \\
Compost (0.1) & $0.227 \mathrm{a}^{*}$ & $1.306 \mathrm{ab}$ & $4.879 \mathrm{bc}$ & $0.620 \mathrm{~b}$ \\
Compost $(0.2)$ & $0.232 \mathrm{a}$ & $1.915 \mathrm{a}$ & $7.606 \mathrm{~b}$ & $0.919 \mathrm{~b}$ \\
Compost (0.4) & $0.241 \mathrm{a}$ & $2.337 \mathrm{a}$ & $9.087 \mathrm{a}$ & $1.671 \mathrm{a}$ \\
Fertilizer (0.0) & $0.110 \mathrm{~b}$ & $1.28 \mathrm{~b}$ & $2.661 \mathrm{bcd}$ & $0.255 \mathrm{bc}$ \\
Control $(0.0)$ & $0.101 \mathrm{~b}$ & $0.245 \mathrm{~b}$ & $2.708 \mathrm{bcd}$ & $0.288 \mathrm{bc}$ \\
& & \multicolumn{2}{c}{ Sodded } \\
Compost $(0.1)$ & $0.227 \mathrm{a}$ & $0.738 \mathrm{~b}$ & $4.442 \mathrm{~b}$ & $0.581 \mathrm{bc}$ \\
Compost $(0.2)$ & $0.237 \mathrm{a}$ & $1.236 \mathrm{~b}$ & $7.044 \mathrm{a}$ & $0.946 \mathrm{~b}$ \\
Compost $(0.4)$ & $0.240 \mathrm{a}$ & $2.291 \mathrm{a}$ & $7.929 \mathrm{a}$ & $1.530 \mathrm{a}$ \\
Fertilizer (0.0) & $0.091 \mathrm{~b}$ & $0.158 \mathrm{bc}$ & $2.156 \mathrm{bc}$ & $0.264 \mathrm{bcd}$ \\
Control $(0.0)$ & $0.055 \mathrm{bc}$ & $.259 \mathrm{bc}$ & $2.266 \mathrm{bc}$ & $0.250 \mathrm{bcd}$ \\
\hline
\end{tabular}

Control plots had higher $\mathrm{pH}$ (6.0) compared to fertilized plots (5.9) (Figure 5). The decrease in $\mathrm{pH}$ of fertilized plots can be attributed to the application of fertilizer with a composition of $\mathrm{NH}_{4}-\mathrm{N}(4.7 \%)$, urea $(8.3 \%)$, other water soluble $\mathrm{N}(6.4 \%)$, and water insoluble $\mathrm{N}(0.6 \%) . \mathrm{NH}_{4}-\mathrm{N}$ fertilizers are known to decrease $\mathrm{pH}$ through leaching of basic cations and production of $\mathrm{H}^{+}$as a result of nitrification [40]. In this study, leaching of basic cations and the resultant exchange with $\mathrm{NH}_{4}{ }^{+}$ions was most likely responsible for the lowering of $\mathrm{pH}$ in fertilized plots. Our results are consistent with those of Rasnake and Murdock [39] and Eghball [2] who reported a decrease in $\mathrm{pH}$ from 6.7-6.3 and 6.4-5.6 respectively, following $\mathrm{NH}_{4}-\mathrm{N}$ fertilizer applications.

Soil CEC increased from $11 \mathrm{cmol}_{\mathrm{c}} \mathrm{kg}^{-1}$ (control) to an average of $28 \mathrm{cmol}_{\mathrm{c}} \mathrm{kg}^{-1}$ with increasing rates of compost application (Figure 6). This can be explained by both the increase in the amount of organic matter due to CPL addition and the concomitant increase in $\mathrm{pH}$ and available cations (Figure 5). The CEC of organic matter ranges from 100-300 $\mathrm{cmol}_{\mathrm{c}} \mathrm{kg}^{-1}$, [29]. The effect of $\mathrm{pH}$ on CEC is most prominent in soils with a significant amount of $\mathrm{pH}$-dependent clays. In our study, the mineralogical composition of soil was not determined, but based on the low CEC of control plots $\left(11 \mathrm{cmol}_{\mathrm{c}} \mathrm{kg}^{-1}\right)$ we believe that it is mostly formed of $\mathrm{pH}$-dependent clays. Gao and Chang [3] also observed increases in CEC following cattle feedlot manure applications and attributed this increase mainly to the increase in organic matter.

In general, the addition of CPL to subsoil improved its nutrient content (Table 1). Higher concentrations of $\mathrm{P}, \mathrm{K}, \mathrm{Mg}$ and $\mathrm{Ca}$ were observed at the high (40\%) compost rate for both seeded and sodded plots. This increase in nutrient content also reflects the rich nutrient composition of composted poultry litter. Levels of basic cations $(\mathrm{Ca}, \mathrm{K}$, and $\mathrm{Mg}$ ) increased linearly and consequently increased base saturation. Gagnon [41] reported an increase of $60 \%$ in available soil P treated with poultry litter as compared with other on-farm and industrial composts. Significantly larger increases in soil P (from 
52\%-240\%) were reported by Balkcom et al. [42]. These increases are due to relatively high content of total P in poultry litter. In studies by Gascho and Hubbard [20], soil P and Ca levels also increased with broiler litter application, while soil K levels decreased. Decrease in soil K was attributed to crop uptake. Our studies demonstrate that composted poultry litter can be used successfully to improve soils where turfgrasses are established in poor subsoil, typically encountered in suburbia.

Figure 6. Effect of incorporating composted poultry litter into top $12.7 \mathrm{~cm}$ of subsoil on cation exchange capacity (CEC) for $\bullet$ sodded compost; o sodded fertilizer; $\boldsymbol{\nabla}$ seeded compost; and $\nabla$ seeded fertilizer plots; * Means with same letters are statistically insignificant based on Fisher's Protected LSD test $(P \leq 0.05)$ (italicized statistics correspond to sodded treatments); ${ }^{\dagger}$ values for standard error were small ranging between 0.065 ( $\mathrm{min}$.) to 0.443 (max.) and hence are not shown in figure.

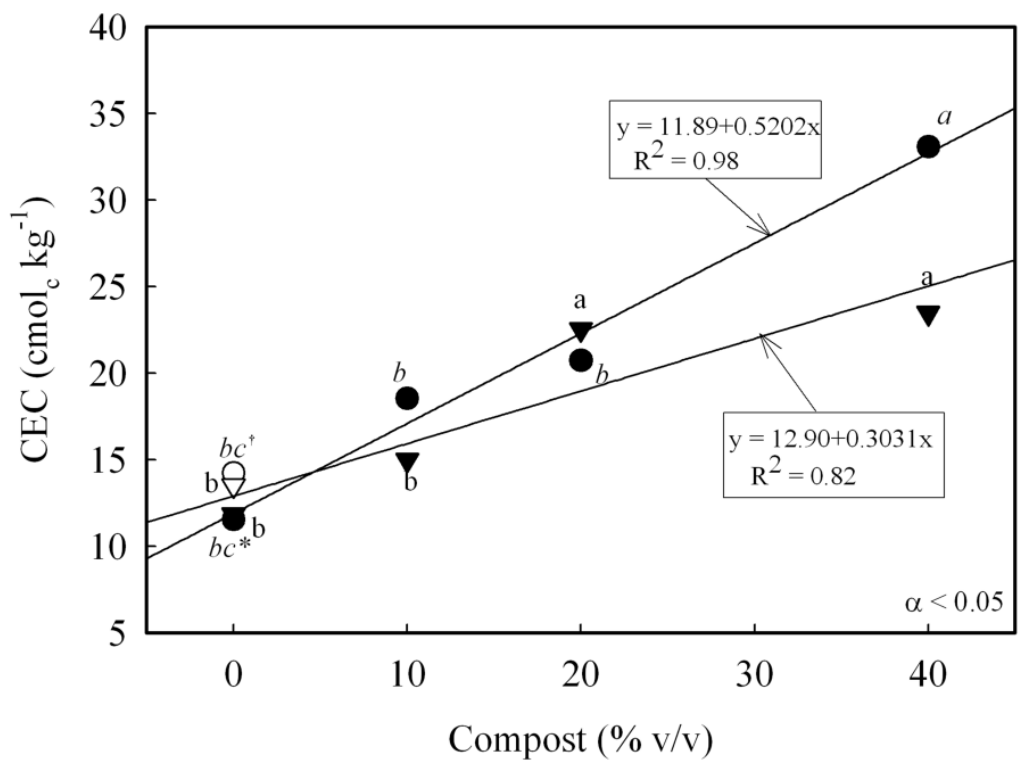

Positive linear increases in $\theta_{T}$, organic matter, $\mathrm{pH}, \mathrm{CEC}$, and mineral nutrient content were observed with a linear decrease in soil bulk density and $A_{v}$ by composted poultry litter incorporation. Improvement in physical and chemical properties of subsoil could be attributed to its dual role of supplying organic matter and essential nutrients, and raising the soil $\mathrm{pH}$ thereby releasing more cations. Both the amount and composition of organic matter added to the soil affect the extent to which its physical and chemical properties are modified. These results demonstrate that composted poultry litter can be used to enhance the soil physical and chemical properties of eroded or disturbed soils. Amending soils with organic wastes can have two advantages; apart from managing the disposal problem it can also improve soil nutrient and organic matter content.

\section{Experimental Section}

Experimental Site: Field experiments were established in fall 2003 at the West Virginia University, Agronomy Farm, Morgantown (39.66N, 79.90W). The soil was a Dormont silt loam (fine-loamy, mixed, superactive, mesic Oxyaquic Hapludalfs). To simulate construction disturbance existing topsoil containing the A-horizon was removed (to a depth of $20 \mathrm{~cm}$ ) and the subsoil was exposed. The exposed 
subsoil was tilled uniformly to a depth of $12.7 \mathrm{~cm}$ using a rototiller and plots $4.6 \mathrm{~m} \times 3.1 \mathrm{~m}$ separated by $0.6 \mathrm{~m}$ alleyways were delineated. The compost utilized for the experiments was derived from poultry litter with wood chips and cardboard as a primary source of carbon with a ratio of 2:2:2 $\left(\mathrm{N}, \mathrm{P}_{2} \mathrm{O}_{5}, \mathrm{~K}_{2} \mathrm{O}\right)$ (Borderline LLC, Baker, WV). Treatments consisted of CPL incorporated to a depth of $12.7 \mathrm{~cm}$ at rates of $0.1 \mathrm{~cm}$-compost/cm-soil, $0.2 \mathrm{~cm}$-compost/cm-soil, and $0.4 \mathrm{~cm}$-compost/cm-soil (equivalent to $4.3 \mathrm{~kg} \mathrm{~m}^{-2}, 8.75 \mathrm{~kg} \mathrm{~m}^{-2}$, and $17.5 \mathrm{~kg} \mathrm{~m}^{-2}$, respectively), control (untreated), and fertilized plots $\left(\mathrm{N}, \mathrm{P}_{2} \mathrm{O}_{5}\right.$, $\mathrm{K}_{2} \mathrm{O}$ fertilizer 20-27-5; applied at $50 \times 10^{-4} \mathrm{~kg} \mathrm{~m}^{-2}$ ). The three compost treatments provided $\mathrm{N}$ at 0.086 , 0.172 , and $0.34 \mathrm{~kg} \mathrm{~m}^{-2}$, whereas the fertilizer treatment provided $\mathrm{N}$ at $0.001 \mathrm{~kg} \mathrm{~m}^{-2}$. The fertilizer was applied using a drop spreader and incorporated lightly $(1 \mathrm{~cm})$ into the soil using a rake. Based on the different depths to which the compost and the fertilizer treatments were incorporated, it was estimated that the compost provided $\mathrm{N}$ at $6.77 \times 10^{-7} \mathrm{~kg} \mathrm{~cm}^{-3}$ whereas the fertilizer provided $\mathrm{N}$ at $10^{-7} \mathrm{~kg} \mathrm{~cm}^{-3}$

The experimental design was a randomized complete block with turf type (seeded or sodded) and amendment treatments arranged factorially. All the treatments were replicated four times. Twenty plots were seeded on 7 October 2003 with Kentucky bluegrass seeds (Scotts "Classic"; 97.75\% Kentucky bluegrass, $0.05 \%$ other crop seeds, $2.11 \%$ inert matter, $0.09 \%$ weed seeds) at the rate of $50 \times 10^{-4} \mathrm{~kg} \mathrm{~m}^{-2}$ using a drop spreader. Seeded plots were covered with straw mulch in order to retain soil moisture and to offer protection from predators. The 20 remaining plots were sodded with Kentucky bluegrass manually on 10 October 2003 with sod (from Rich Farm, Smithfield, PA, USA). Plots were irrigated uniformly as needed during establishment. After establishment, the turf was maintained at a height of $7.6 \mathrm{~cm}$ using a reel-mower and clippings removed. Rainfall data were collected during the months of May through September 2004 (Table 2).

Table 2. Precipitation recorded from May to September in 2004.

\begin{tabular}{cc}
\hline Month & Precipitation amount (cm) \\
\hline May & 13.36 \\
June & 12.45 \\
July & 9.02 \\
August & 16.23 \\
September & 17.07 \\
Total & 68.12 \\
\hline
\end{tabular}

Soil Analysis: Soil samples were collected twice at a depth of $20.3 \mathrm{~cm}$ from each plot during the study using a soil probe. At each sampling time, 7-8 subsamples were collected from random locations within each plot and were mixed thoroughly to make one composite sample. Samples collected during February 2004 were air dried, machine ground and sieved through a 2-mm screen, and were analyzed for CEC and levels of extractable $\mathrm{Ca}, \mathrm{P}, \mathrm{Mg}$, and $\mathrm{K}$. Soil samples were collected again as described above during January 2005 and were manually cleaned for any pebbles and debris and then air dried, hand ground, sieved through a 2-mm screen was used to analyze available water and organic matter content. The $\mathrm{pH}$ in water was measured with a glass electrode using a 1:1 soil/water ratio [43]. Soil organic matter (OM) was determined by the loss on ignition method (LOI) [44]. The LOI was corrected for dehydroxylation of inorganic constituents through regression analysis prior to determination of the actual OM content. 
The following equation derived from the Walkley Black method was used to correct for soil types in Northeast and North Central states [44].

$$
\mathrm{OM}=[(0.8 \times \mathrm{LOI} \%)-0.23]
$$

The CEC was determined by ammonium acetate-Kjeldahl method (1.0 N NH $4 \mathrm{OAc}, \mathrm{pH} 7.0)$ [45]. Calcium, Mg, $\mathrm{K}$ and, $\mathrm{P}$ were extracted using the Mehlich 1 procedure [46]. Calcium, $\mathrm{P}$, and $\mathrm{Mg}$ were determined using inductively coupled plasma (ICP). Potassium was measured with atomic absorption spectrophotometry (Perkin Elmer Model 100, Perkin Elmer Corp., Norwalk, CT, USA).

Soil texture was determined using the pipette method [47]. Non-disturbed soil cores of known volume $\left(3.47 \times 10^{-4} \mathrm{~m}^{3}\right)$ were collected to determine bulk density using a hammer-driven core sampler. Bulk density was determined by measuring the mass (dried at $105^{\circ} \mathrm{C}$ ) and volume of soil in each core. To determine available water $\left(A_{v}\right)$, soil samples were saturated with distilled water and desorbed at $3.3 \times 10^{4}$ and $1.5 \times 10^{6} \mathrm{~Pa}$ pressure using the pressure plate method [48]. To determine total water content, fresh soil samples of known volume $\left(3.47 \times 10^{-4} \mathrm{~m}^{3}\right)$ were taken from the field and their moist weights were recorded immediately. Samples were kept in an oven at $105{ }^{\circ} \mathrm{C}$ for $48 \mathrm{~h}$ and the dry weight was recorded.

Data Analysis: Analysis of variance was used to analyze the data using PROC GLM ${ }^{\mathrm{TM}}$ procedure of the Statistical Analysis System (SAS Institute, 2002). Fisher's Protected Least Significant Difference (LSD) test, with a probability value of 0.05 , was used to separate treatment means.

\section{Conclusions}

In conclusion, our research determined that physical and chemical characteristics of subsoil, that govern turfgrass growth, could be improved significantly by composted poultry litter incorporation. Various field studies have demonstrated the benefits and risks of poultry litter application to soils used to grow food and fiber crops. In our experiment, composted poultry litter incorporation into a silt-loam subsoil, used to grow turfgrasses, improved its physical and chemical properties. Specifically, increases in total water content, organic matter, $\mathrm{pH}$, and cation exchange capacity were noted following incorporation of the compost material. Overall, compost treatments were able to significantly improve soil physical and chemical properties compared to conventionally fertilized and control plots.

\section{Acknowledgments}

The experiment was funded through USDA Hatch Project no. 438. The authors wish to thank Borderline LLC., for their generous donation of compost materials used in this experiment.

\section{Conflicts of Interest}

The authors declare no conflict of interest.

\section{References}

1. Daniels, W.L.; Amos, D.F. Generating productive topsoil substitutes from hard rock overburden in the southern Appalachians. Environ. Geochem. Health 1984, 7, 8-15. 
2. Eghball, B. Soil properties as influenced by phosphorus and nitrogen based manure and compost applications. Agron. J. 2002, 94, 128-135.

3. Gao, G.; Chang, C. Changes in CEC and particle size distribution of soils associated with long term annual applications of cattle feedlot manure. Soil Sci. 1996, 161, 115-120.

4. Nyakatawa, E.Z.; Reddy, K.C.; Sistani, K.R. Tillage, cover cropping, and poultry litter effects on selected soil chemical properties. Soil Tillage Res. 2001, 58, 69-79.

5. Tyson, S.C.; Cabrera, M.L. Nitrogen mineralization in soils amended with composted and uncomposted poultry litter. Commun. Soil Sci. Plant Anal. 1993, 24, 2361-2374.

6. Sharpley, A.N.; Smith, S.J.; Bain, W.R. Nitrogen and phosphorus fate from long-term poultry litter application to Oklahoma soils. Soil Sci. Soc Am. J. 1993, 57, 1131-1137.

7. Kelleher, B.P.; Leahy, J.J.; Henihan, A.M.; O’Dwyer, T.F.; Sutton, D.; Leahy, M.J. Advances in poultry litter disposal technology-A review. Bioresour. Tech. 2002, 83, 27-36.

8. Haapapuro, E.R.; Barnard, N.D.; Simon, M. Animal waste used as livestock feed: Dangers to human health. Prev. Med. 1997, 26, 599-602.

9. Chang, C.; Janzen, H.H. Long-term fate of nitrogen from annual feedlot manure applications. $J$. Environ. Qual. 1996, 25, 785-790.

10. Goyne, K.W.; Jun, H.J.; Anderson, S.H.; Motavalli, P.P. Phosphorus and nitrogen sorption to soils in the presence of poultry litter-derived dissolved organic matter. J. Environ. Qual. 2008, 37, 154-163.

11. Paul, E.A. Soil microbiology, ecology, and biochemistry in perspective. In Soil Microbiology and Biochemistry, 3rd ed.; Paul, E.A., Ed.; Academic Press: San Diego, CA, USA, 1996; pp. 13-17.

12. Millner, P.D.; Sikora, L.J.; Kaufman, D.D.; Simpson, M.E. Agricultural uses of biosolids and other recyclable municipal residues. In Agricultural Uses of Municipal, Animal, and Industrial Byproducts; Conservation Research Report 44; Wright, R.J., Kemper, W.D., Millner, P.D., Power, J.F., Korcak, R.F., Eds.; USDA Agriculture Research Service: Washington, DC, USA, 1998; pp. 9-44.

13. Vadas, P.A.; Meisinger, J.J.; Sikora, L.J.; McMurtry, J.P.; Sefton, A.E. Effect of poultry diet on phosphorus in runoff from soils amended with poultry manure and compost. J. Environ. Qual. 2004, $33,1845-1854$.

14. Epstein, E.; Taylor, J.M.; Chaney, R.L. Effects of sewage sludge and sludge compost applied to soil on some soil physical and chemical properties. J. Environ. Qual. 1976, 5, 422-426.

15. Tester, C.F. Organic amendment effects on physical and chemical properties of a sandy soil. Soil Sci. Soc. Am. J. 1990, 54, 827-831.

16. Avimelech, A.; Cohen, A.; Shkedi, D. The effect of municipal solid waste compost on the fertility of clay soils. Soil Tech. 1990, 3, 275-284.

17. Shiralipour, A.; McConnell, D.B.; Smith, W.H. Physical and chemical properties of soils as affected by municipal solid waste compost application. Biomass Bioenerg. 1992, 3, 261-266.

18. Tiarks, A.E.; Mazurak, A.P.; Chesnin, L. Physical and chemical properties of soil associated with heavy applications of manure from cattle feedlots. Soil Sci. Soc. Amer. Proc. 1974, 38, 826-830.

19. He, Z.; Tazisong, I.A.; Senwo, Z.N.; Zhang, D. Soil properties and macro cations status impacted by long-term applied poultry litter. Commun. Soil Sci. Plant Anal. 2008, 39, 858-872. 
20. Gascho, G.J.; Hubbard, R.K. Long-term impact of broiler litter on chemical properties of a coastal plain soil. J. Soil Water Conserv. 2006, 61, 65-74.

21. Barker, A.V. Evaluation of composts for growth of grass sod. Comm. Soil Sci. Plant Anal. 2001, 32, 1841-1860.

22. Harrell, M.S.; Miller, G.L. Composted yard waste affects soil displacement and roadside vegetation. HortScience 2005, 40, 2157-2163.

23. Linde, D.T.; Hepner, L.D. Turfgrass seed and sod establishment on soil amended with biosolid compost. HortTechnology 2005, 15, 577-583.

24. O'Brien, T.A.; Barker, A.V. Evaluation of field-applied fresh composts for production of sod crops. Compost Sci. Utlzn. 1995, 3, 53-65.

25. Wright, A.L.; Provin, T.L.; Hons, F.M.; Zuberer, D.A.; White, R.H. Compost impacts on sodicity and salinity in a sandy loam turf grass soil. Compost Sci. Utlzn. 2008, 16, 30-35.

26. Mandal, M.; Chandran, R.S.; Balasko, J. Amending subsoil with composted poultry litter-II: Effects on Kentucky bluegrass (Poa pratensis L.) establishment, root growth, and weed populations. Agronomy, 2013, in press.

27. Stevenson, F.J. Humus Chemistry: Genesis, Composition, Reactions; John Wiley \& Sons: Hoboken, NJ, USA, 1994; pp. 1-24.

28. Evangelou, V.P. Environmental Soil and Water Chemistry-Principles and Applications; John Wiley \& Sons, Inc.: New York, NY, USA, 1998; pp. 24-38.

29. Hillel, D. Introduction to Environmental Soil Physics; Elsevier-Academic Press: San Diego, CA, USA, 2004; pp. 363-407.

30. Jamison, V.C. Changes in air-water relationships due to structural improvement of soils. Soil Sci. 1953, 76, 143-151.

31. Stevenson, E. Influence of peat moss on soil water retention for plants. Can. J. Soil Sci. 1974, 54, 109-110.

32. Reeve, M.J.; Smith, P.D.; Thomasson, A.J. The effect of density on water retention properties of field soils. J. Soil Sci. 1973, 24, 356-367.

33. Angle, J.S.; Wolf, D.C.; Hall III, J.R. Turfgrass growth aided by sludge compost. BioCycle 1981, $22,40-43$.

34. Jamison, V.C.; Kroth, E.M. Available moisture storage capacity in relation to textural composition and organic matter content of several Missouri soils. Soil. Sc. Soc. Am. Proc. 1958, 22, 189-192.

35. Metzger, L.; Yaron, B. Influence of sludge organic matter on soil physical properties. Adv. Soil Sci. 1987, 7, 141-163.

36. MacRae, R.J.; Mehuys, G.R. The effect of green manuring on the physical properties of temperate area soils. Adv. Soil Sci. 1985, 3, 71-94.

37. McConnell, D.B.; Shiralipour, A.; Smith, W.H. Compost application improves soil properties. BioCycle 1993, 34, 61-63.

38. Wei, Q.F.; Lowery, B.; Peterson, A.E. Effect of sludge application on physical properties of silty clay loam soil. J. Environ. Qual. 1985, 14, 178-180.

39. Rasnake, M.; Sikora, F.; Murdock, L. Nutrient accumulation and movement in soils following the use of poultry litter. In Animal, Agricultural and Food Processing Wastes, Proceedings of the Eighth International Symposium, Des Moines, USA, 9-11 October 2000; pp. 562-567. 
40. Havlin, J.L.; Beaton, J.D.; Tisdale, S.L.; Nelson, W.L. Soil Fertility and Fertilizers, An Introduction to Nutrient Management; Prentice Hall: Upper Saddle River, NJ, USA, 1999; p. 499.

41. Gagnon, B. Contribution of on-farm and industrial composts to soil $\mathrm{pH}$ and enrichment in available nutrients and metals. Can. J. Soil Sci. 2004, 4, 439-445.

42. Balkcom, K.S.; Adams, J.F.; Hartzog, D.L. Peanut yield response to poultry litter and municipal sludge application. Commun. Soil Sci. Plant Anal. 2003, 34, 801-814.

43. Thomas, G.W. Soil pH and soil acidity. In Methods of Soil Analysis; Chemical Methods-SSA Book Series No. 5; Soil Science Society of America and American Society of Agronomy: Madison, WI, USA, 1996; pp. 475-490.

44. Nelson, D.W.; Sommers, L.E. Total carbon, organic carbon, and organic matter. In Methods of Soil Analysis; Chemical Methods-SSA Book Series No. 5; Soil Science Society of America and American Society of Agronomy: Madison, WI, USA, 1996; pp. 961-1010.

45. Sumner, M.E.; Miller, W.P. Methods of Soil Analysis; Chemical Methods-SSA Book Series No. 5; Soil Science Society of America and American Society of Agronomy: Madison, WI, USA, 1996; pp. 1201-1229.

46. Mehlich, A. Determination of $\mathrm{P}, \mathrm{Ca}, \mathrm{Mg}, \mathrm{K}, \mathrm{Na}$ and $\mathrm{NH}_{4}$; Short test methods used in soil testing division, Department of Agriculture: Raleigh, NC, USA, 1953; pp. 1-53.

47. Gee, G.W.; Bauder, J.W. Particle-size analysis. In Methods of Soil Analysis; Chemical Methods-SSA Book Series No. 5; Soil Science Society of America and American Society of Agronomy: Madison, WI, USA, 1986; pp. 383-409.

48. Klute, A. Water retention: laboratory methods. In Methods of Soil Analysis; Chemical Methods-SSA Book Series No. 5; Soil Science Society of America and American Society of Agronomy: Madison, WI, USA, 1986; pp. 635-660.

(C) 2013 by the authors; licensee MDPI, Basel, Switzerland. This article is an open access article distributed under the terms and conditions of the Creative Commons Attribution license (http://creativecommons.org/licenses/by/3.0/). 